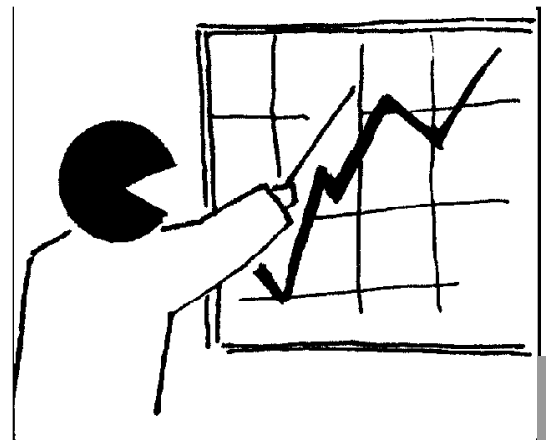

МЕТОДИКА НАВЧАННЯ I ВИХОВАННЯ

УДК

IВАННА ЗЕМАН, аспірант кафедри загальної педагогіки та дошкільної освіти, Дрогобииький державний педагогічний університет імені Івана Франка, Украӥна igafycz@gmail.com

\title{
ФОРМУВАННЯ КОМПЕТЕНТНОСТЕЙ УЧНІВ БАЗОВОЇ СЕРЕДНЬОЇ ШКОЛИ
}

IVANNA ZEMAN, PhD Student of the General Pedagogy and Preschool Education Department, Drohobych Ivan Franko State Pedagogical University, Ukraine

\section{COMPETENCE BULDING OF BASIC SECONDARY EDUCATION STUDENTS}

Стаття присвячена розгляду процесу формування компетентностей в учнів базової середньої школи, оскільки ринок праці у XXI столітті потребує професіоналів, котрі вміють учитися протягом життя, критично мислити та досягати цілей. Автором обгрунтовано одне $з$ важливих завдань учителів, що полягає у правильному формуванні життєвих компетентностей, які мають неабияке значення для успішної самореалізації, освіти та праці. Доведено, що все більша низка шкіл розглядають компетентності як візитівку школи, адаптують пропозиції до потреб освітян, проводять консультації та тренінги для вчителів, щоб максимально підвищити свій рівень викладання.

Ключові слова: компетентність, формування компетентності, учень, школа, освіта.

Summary. The article explores the process of competence building of basic secondary education students. The professionals who are good at life-

(C) I. Земан long learning, critical thinking, goal-setting and goal-achieving are highly required in the job market of the 21 st century. One of the most important teacher's tasks lies in proper development of life competencies which are essential for successful self-fulfillment, education and labour. A growing number of schools tend to offer a range of competencies as a visiting card by adapting their offers to the educators' needs, providing consultations and teacher trainings for the purpose of maximizing their teaching level.

Key words: competence, forming competence, student, school, education.

Мета: охарактеризувати особливості формування компетентностей в учнів базової школи.

Постановка проблеми в загальному вигляді. Сучасний світ ставить перед нами складні вимоги, зокрема, учнями базової школи. Визначення таких вимог може покращити ефективність підготовки учнів до дорослого життя, у якому особистість здатна вирішити життєві проблеми, а також загальні цілі для систем освіти та навчання протягом усього життя.

Перебудова освіти в Україні, а саме шкільної, запровадження Нової української школи (далі НУШ) $є$ ключовою реформою галузі. Філософія освіти НУШ відмовляється від пострадянського режиму навчання та наголошує, що учням потрібно давати не лише знання на теоретичному рівні, але й навчитися ними користуватися на практиці у школі та за ¥ї межами, тобто у повсякденному житті.

Аналіз досліджень і публікацій. Упровадження та формування компетентностей учнів, зокрема базової школи, грунтовно досліджували: І. Бех, Г. Бібік, С. Гончаренко, I. Єрмаков, О. Локшина О. Овчарук, I. Підласий, О. Пометун, І. Родигіна, О. Савченко, О. Хуторський та інші.

Поняття "компетентність" $\epsilon$ доволі новим, однак попри свою новизну посіло досить важливе місце в галузі науки. Пошук та розробка оптимальних методів і процедур 3 урахуванням усіх аспектів, що супроводжують освітні ситуації в сучасному 
світі, стає важливим завданням сьогодення.

Виклад основного матеріалу дослідження. У XXI столітті поняття "компетентність" $\epsilon$ дуже важливим у галузі освіти, тому Міністерство освіти і науки України подає означення компетентності як динамічної комбінації знань, умінь, навичок, способів мислення, поглядів, цінностей, інших особистісних якостей, що визначає здатність учня успішно соціалізуватися, провадити професійну та/або подальшу навчальну діяльність. Таким чином, формується ядро знань, на яке будуть накладатись уміння користуватися цими знаннями, а також цінності та навички, що знадобляться випускникам української школи у професійному та приватному житті. Щоб набувати компетентностей, школярі навчаються за діяльнісним підходом, тобто частіше щось роблять замість того, щоб просто сидіти за партами і слухати вчителя (Нова українська школа).

У 2019 році розроблено проєкт Державного стандарту базової середньої освіти. Документом визначено: мету та принципи організації освітнього процесу в закладах загальної середньої освіти II ступеня (5-9 класи); зміст ключових компетентностей здобувачів базової середньої освіти; вимоги до обов'язкових результатів навчання та компетентностей здобувачів базової середньої освіти; загальний обсяг навчального навантаження здобувачів у базових навчальних планах; підходи до оцінювання навчальних досягнень учнів (Ocвітня реформа: результати та перспективи, 2019, с. 61).

Закон України "Про повну загальну середню освіту" до основних компетентностей Нової української школи відносить такі, як: вільне володіння державною мовою, здатність спілкуватися рідною (у разі відмінності від державної) та іноземними мовами, математична компетентність, компетентності в галузі природничих наук, техніки і технологій, інноваційність, інформаційно-комунікаційна компетентність, навчання впродовж життя, підприємливість та фінансова грамотність, громадянські та соціальні компетентності, пов'язані з ідеями демократії, справедливості, рівності, правами людини, добробутом та здоровим способом життя, усвідомленням рівних прав і можливостей, культурна компетентність, екологічна компетентність, інші компетентності, передбачені стандартом освіти (Новий закон Украӥни "Про освіту", с. 2). Перелік цих компетентностей збігається 3 переліком стандартів ЄС, тобто ці компетентності стосуються не лише України, але й усіх європейських країн. Проте немає єдності у виділенні навчальних компетентностей. Різні варіанти можна знайти в літературі, інтернет ресурсах та на освітніх сайтах. Кожна школа представляє певний набір компетентностей як iii візитівку, що надає пріоритету порівняно 3 іншими закладами.

Формування компетентностей учнів зумовлене не тільки реалізацією відповідного оновлення змісту освіти, а й адекватних методів і технологій навчання. Але зміст та методика викладання будь-якого предмета мають певні специфічні риси стосовно формування компетентностей учнів (3всрєва, 2008, с. 9).

У різноманітних друкованих та електронних виданнях можна знайти рекомендації, а також поради щодо формування й розуміння компетентностей учнів 59 класів.

Так, I. Підласий порівнює вчителя, котрий навчає учнів базової школи, з портретом супермена. "Як на мене, дуже доречно, бо не кожний кіношний герой ризикне зайти до класу 3 обтяженими своїми проблемами підлітками. ... А стояти кожного дня перед не завжди шанобливими учнями, сіяти добре і вічне для тих, хто цьому опирається, тут необхідна неабияка мужність" (Підласий, 2019, с. 40). Саме мужність, сміливість і відвагу науковець також відносить до педагогічних компетентностей вчителя.

Давані Прістер подає власні рекомендації щодо правильного формування компетентностей в учнів середньої школи та наголошує на необхідності технологій, які необхідно трактувати як природну частину навчання, тому що настав час зіткнутися 3 правдою: сьогоднішні учні матимуть дуже мало поняття життя без технологій та стверджує, що уроки мають бути міждисциплінарними, учні розвивають свої навички та знання XXI століття, коли вони дізнаються, чому кожна навчальна дисципліна важлива.

Серед основних компонентів найперше місце займають компетентності середньої школи, які складаються 3 навичок, необхідних для успіху учнів у школі та за іiі межами.

До компетентностей, які є основними для учнів базової школи, оскільки водночас розглядаються як інтелектуальні, особистісні та соціальні навички, які розвиватимуться у процесі навчання, належать спілкування, критичне мислення, співпраця та лідери навчання.

Спробуємо коротко охарактеризувати кожен 3 них. Компетентність комунікацій охоплює основний набір навичок та вмінь, важливих для ефективного обміну інформацією, ідеями, досвідом, а також для взаємодії та вивчення навколишнього світу.

Компетентність критичного мислення втілює знання, уміння та процеси, пов'язані 3 інтелектуальним розвитком, продемонстровані як через творче, так i критичне мислення.

Компетентність у співпраці має важливе значення для того, щоб допомогти учням розвивати вміння, звички та нахили працювати в межах громади для досягнення спільних цілей.

Лідери навчальних компетентностей найкраще представлені в особистій та соціальній свідомості і важливості особистої відповідальності.

Ці основні компетентності, крім інших складових навчальної програми, покликані забезпечити учням навички, необхідні для досягнення майбутніх успіхів (Dwayne Priester, 2017).

Але, напевно, більшість учнів, виходячи від першої вчительки, до кінця ще не розуміють слово "компетентність", а деякі і взагалі не знають. У такому випадку I. Підласий радить підготувати коротеньку промову перед п'ятикласниками на тему "Хочу стати компетентним" (Підласий, 2019, 
c. 36). Зокрема, до слова "компетентний" підібрати простіші синоніми, або замінити його доступнішими словами.

Варто погодитися 3 науковцями, що найбільший результат у формуванні компетентностей дає самостійна робота. Але зараз учням найбільшу цікавість приносять телефони, планшети, тобто пошук інформації в інтернеті. То чому не поєднати б корисне 3 приємним? Тут має місце гібридне навчання, яке дозволяє використовувати мережу інтернет під час уроку для самостійного навчання за присутності вчителя (Підласий, 2019, с. 21).

Прикладом може слугувати гібридний урок для засвоєння компетентностей для учнів 5-го класу на прикладі статті про дельфінарій (Підласий, 2019, с. 25). Вони в мережі інтернет шукають статтю, яку вказав вчитель, на сайті, записаному заздалегідь на дошці, і уважно перечитують її. Стаття має бути невелика за обсягом, щоб учні змогли вдуматися. Після того, як вони прочитали текст, необхідно заховати планшети. На основі прочитаного тексту школярі виконують дослідження і роблять практичні висновки. Кожен 3 них повинен отримати аркуш із заздалегідь підготовленими завданнями, щоб не відволікати інших. Якщо виникне запитання, учень може тихенько покликати вчителя.

Наступним кроком стане організація компетентнісного тестування. Учні приступають до виконання завдань 3 короткими та обгрунтованими відповідями. Такий тест призначений для перевірки обчислюваних екологічних, етичних компетентностей учнів 5-6 класів, але схожі проекти можна використовувати i для старших класів (Підласий, 2019, c. 26).

Окремі науковці зазначають, що для кращого формування компетентностей необхідно нове середовище, яке забезпечить учням можливість навчатися поза приміщенням навчального закладу - у сучасних музеях, лабораторіях, обсерваторіях 3 доступом до відкритих навчальних курсів та інших ресурсів. Тут чільне місце посідає музейна педагогі- ка, яка може стати дієвим інструментом для формування окремих компетентностей (Беззуб, 2013, с. 10). Діти проявляють неабиякий інтерес до таких заходів, де можна не тільки розглядати музейні експонати, раритетні речі, але й доторкнутись до них, узяти деякі речі в руки. Приваблює і сам факт походу в музей, екскурсії.

Так, у Данії використовують такий цікавий метод, як Projekt Edison (проєкт Едісона). Це програма, адресована учням 6-7 класів школи, яка заснована на винахідливості. У ході проєкту учні навчаються розробляти концепції, виробляти продукцію. Одне із завдань програми - стимулювати зацікавлення школярів.

Під час занять, особливо в галузі точних наук, учителі використовують різноманітні допоміжні матеріали, які допомагають учням зрозуміти абстрактні поняття. Зокрема, ідеться про:

- гнучкий день навчання, а також ініціативу "Відкрита школа". Учні частіше беруть участь у заходах поза школою, наприклад: відвідування природничого музею, уроки в геологічному музеї, ботанічному саду.

- підготовку презентацій. Учням часто пропонують підготувати презентації, що стає підбиттям підсумків про поїздку до музею чи обговорення тематичного блоку. Для цього використовуються дошки, малюнки та мультимедійні посібники (Jan Fazlagic, 2018, p. 39, 40).

Заслуговує уваги також формування компетентностей фінської шкільної освіти для учнів 1-6, 7-9 класів (з 2019 року). Тут акцентується на тому, щоб для вирішення завдань майбутнього зосереджуватись на розвитку міждисциплінарних компетентностей, елементах вивчення кожного предмета. Зокрема, ідеться про формування наступних компетентностей:

уміння вчитися;

комунікативні компетенції: взаємодія, виразність;

компетенції ІКТ;

багатограмотність і вміння інтерпретувати складні тексти; інновації та підприємництво; уміння організовувати власну роботу.

Отже, навчальні програми у фінських школах ставлять за мету розвиток усіх шести компетентностей у процесі вивчення кожного шкільного предмета. Це i $є$ новим способом поєднання компетентності та викладання на основі предмета.

Цікавим вважаємо і той факт, що учні можуть брати участь у процесі планування проєкту. Учителі вільно обирають методи роботи з урахуванням цілей, передбачених навчальною програмою. Так, у Фінляндії вона включає загальні рекомендації та рекомендації стосовно методів навчання, матеріалів без конкретизації деталей. Учитель користується великою довірою та соціальною повагою - він самостійно вибирає методи роботи, i це ніким не ставиться під сумнів (Jan Fazlagic, 2018, c. 44, 45). Якщо ж учитель вирішив провести звичайний урок, то науковці радять у такому разі пояснювати матеріал три рази. Перший раз його деталізують, другий - скорочують, третій - викладаються лише головні думки. Це пов'язано з тим, що в одному класі вчаться діти 3 різними типами сприйняття.

Під час такого уроку також можна використовувати схеми опорних сигналів чи просто опор. Досліджено, що серед учнів, котрі не встигають, найчастіше ті, котрим важко запам'ятовувати правила, алгоритми, виконувати завдання і саме коли вони бачать плакат або чують потрібну інформацію у вигляді опорних схем, то їм необхідно відволікатись на пригадування потрібної інформації, а уся їхня увага зосереджується на мисленні (Підласий, 2019, с. 37).

Для формування основних компетентностей учнів 8-9 класів важливо визначити особистісно значимі життеві цінності, оскільки школярі цієї вікової категорії часто розмірковують про своє майбутнє, про місце в житті, у товаристві однолітків (Ляшенко, Жука та ін., 2017, с. 61).

Проведені дослідження науковцями стверджують, що діти цього віку більш зацікавлені природничими науками.

I, що дуже приємно, до найбільш важливих життєвих 
цінностей учні відносять здоров'я і сім'ю, а характерною рисою сучасних випускників базової школи є готовність і прагнення у досягненні життєвих цінностей покладатися на себе і на свої цінності (Ляшенко, Жука та ін., 2017, c. 63).

У наш час розглядаються різні способи інтеграції та вимірювання навичок XXI століття. Шанхай зараз використовує тести PISA - найбільше у світі компетентнісне дослідження для 15річних учнів середньої освіти.

Україна вперше взяла участь у даному дослідженні 2018 року. Наслідком стало отримання результатів, що вказує на визначення рівня володіння трьома компетентностями: читання: 37-42; математика: 41-46; природничі науки: 35-42 (Результати PISA по Україні).

Грамотність 3 читання визначається як здатність особистості розуміти, використовувати, розмірковувати та спілкуватися 3 написаним текстом для досягнення своїх цілей, розвитку знань та потенціалу, участі в суспільстві (OECD, 2017, p. 17).

Математична грамотність - це здатність особистості міркувати математично та формулювати, використовувати та інтерпретувати математику для вирішення проблем у різних контекстах реального світу. Вона включає поняття, процедури, факти та інструменти для опису, пояснення, прогнозування явищ. Це допомагає усвідомити значення математики, приймати обгрунтовані судження та рішення, необхідні конструктивним, рефлексивним громадянам XXI століття (PISA 2021 Mathematics Framework). Грамотна людина здатна вести дискусії про науку та техніку, що вимагає компетенцій для пояснення явищ, наукового оцінювання та проєктування досліджень, інтерпретування даних (OECD, 2017, p. 17).

Ми цілком погоджуємось 3 думкою учених: "чим компетентніші вчителі, тим вища якість освіти" (Підласий, 2019, с. 6). За визначенням А. Маркової, професійно компетентною $є$ така праця вчителя, у якій на досить високому рівні здійснюється педагогічна діяльність, педагогічне спілкування, реалізується особистість учителя і досягнуто хороших результатів у навченості і вихованості школярів (Токарева, 2013, c. 189).

Іноземні науковці особливу увагу привертають до вчителя як до фахівця, який навчає інших не тільки власного предмета, але й представляє світ цінностей, запускає активність у своїх учнів та підтримує їх. У працях Гелени Мерзек наголошується: "найважливішою метою вчителя має бути добро учня, його інтелектуальний (розумовий) та етичний (моральний) розвиток" (Marzec, $2014, p$ 39). Також важливо для педагога вміти користуватися сучасними технологіями та проходити стажування для підвищення кваліфікації (Marzec, 2014 , p. 38,43$)$. До основних вимог, я це висока моральність, духовність, чесність, відповідальність, порядність і чистота. "Духовною може виховати підростаючу людину лише духовний педагог" (Підласий, 2019, с. 39).

Для перевірки компетентностей вчителя також розроблені тести, які перевіряють основні навички, загальні, предметні та педагогічні знання. Більшість країн світу використовують ETS (Служба тестування освіти) під назвою Praxis, яка вимірює базові знання з математики, читання та письма. Серія Praxis II допомагає дослідити рівень загальних, професійних знань, комунікативних навичок і містить 126 предметних іспитів, включаючи всі наукові дисципліни шкільної програми (Підласий, 2019, с. 67).

Висновки та перспективи подальшого дослідження. Підсумовуючи проведене дослідження, варто зазначити, що впровадження ідей НУШ стало великим кроком до переосмислення освітньої парадигми, де основне завдання школи спрямовується на створення умов для розвитку компетентної особистості. Саме тому формування компетентностей стало важливим не лише для української освіти, але і європейської загалом.

Чільне місце у формуванні основних компетентностей посідають новітні технології, які $€$ невід'ємною частиною сучасно- го учня. Саме вони дають можливість реалізовувати його бажання, а також допомагають учителям зробити урок цікавішим, а матеріал доступнішим.

Для формування компетентностей в учнів вартісними $є$ нові підходи до навчання: участь у дослідницьких проєктах, уроки у формі гри, відвідування музеїв, створення презентацій, самостійна підготовка доповідей тощо. Не менш важливою є професійна компетентність учителів, від яких залежить, чи зможе учень максимально розкрити свої можливості.

\section{СПИСОК ЛІТЕРАТУРИ}

Беззуб, Ю. В. (2013). Методи та прийоми музейної педагогіки в шкільному навчально-виховному процесі. Матеріали науково-практичної конференції (24-25 вересня 2013 р.). Київ, $10-12$.

Звєрєва, Г. Ф. (2008). Компетентнісний підхід до навчання на уроках математики. Харків : РМК Московського РУО.

Концепція Нової української школи: "Нова Українська школа". Міністерство освіти і науки. Взято 3 https://mon.gov.ua/ua/tag/ nova-ukrainska-shkola

Освітня реформа: результати та перспективи. (2019). Інформаційно-аналітичний збірник Міністерства освіти і науки України. Київ, 227.

Про освіту. Новий закон України. Взято $3 \mathrm{https} / / /$ mon.gov.ua/ $\mathrm{s}$ t o r a g e / a p p / m e d i a / $\mathrm{z}$ a g a $1 \mathrm{n}$ a \% $20 \mathrm{~s}$ er ed n y a / BOOKLETTE_INFO-ZAKON2018 PRESS.p̄ $\bar{d} f$

Підласий, I. П. (2019). Як стати компетентним педагогом? (Ч. 1). Харків : Вид. група "Основа". Підласий, І. П. (2019). Як стати компетентним педагогом? (Ч. 2). Харків : Вид. група "Основа". Підласий, І. П. (2019). Як стати компетентним педагогом? (Ч. 3). Харків : Вид. група "Основа". Результати PISA по Україні. Взято 3 https://osvitoria.media/ experience/rezultaty-pisa-poukrayini-v-chomu-nashi-sylnistorony/

Ляшенко, О. І., Жук, Ю. О., Ващенко, Л. С., Науменко, С. О., Гривко А. В. (2017). Тестові тех- 
нології оцінювання компетентностей учнів. Київ : Видавничий дім "Сам".

Токарева, Н. М. (2013). Основи педагогічної психології. Кривий Ріг.

Dwayne Priester Middle School Principal-2017. Retrieved from https://www.midpac.edu/ blogs/dpriester/2017/11/middleschool-core-competencies.php

Jan, Fazlagic, (2018). Szkola dla innovatora. Ksztaltowanie kompetencji proinnowacyjnych. Kalisz : Wydawca "Osrodek Doskonalenia Nauczycieli".

Marzec, H. (2014). Wspolczesny nauczyciel, jego zadania i rozwoj zawodowy. Імідж сучасного педагога, 8, 38-43.

OECD. (2017), PISA for Development Assessment and Analytical Framework: Reading, Mathematics and Science, Preliminary Version, OECD Publishing, Paris. Retrieved from https://www.oecd.org/pisa/pisafor - d evelopment/P I S A - D Assessment-and-AnalyticalFramework-Ebook.pdf

PISA. (2021). Mathematics Framework. Retrieved from https:/ /pisa2021-maths.oecd.org/

\section{REFERENCES}

Bezzub, Yu. V. (2013). Metody ta pryiomy muzeinoi pedahohiky $v$ shkilnomu navchalnovykhovnomu protsesi [The methods and techniques of museum pedagogy in the school educational process]. Materialy naukovopraktychnoi konferentsii (24-25 veresnia 2013 r.). Museum Pedagogy - Problems, Present, Prospects. Proceedings of the Scientific and Practical Conference (September 24-25,
2013). Kyiv.

Zvereva, H. F. (2008.) Kompetentnisnyi pidkhid do navchannia na urokah matematyky: metodychnyi posibnyk dlia vchyteliy. [A competence approacha in mathematics lessons: textbook for teachers]. Kharkiv.

Kontseptsiia Novoi ukrainskoi shkoly: [New Ukrainian School]. Ministry of Science and Education of Ukraine. Retrieved from https:/ / mon.gov.ua/ua/t a g/nova ukrainska-shkola [in Ukrainian].

Osvitnya reforma: rezultaty ta perspektyvy. (2019). [Educational reform: results and prospects]. Collection information and analytical Ministry of Science and Education of Ukraine. Kyiv.

Pro osvitu. Novyi zakon Ukrainy. [The new Ukrainian law "On Education]. Retrieved from https://mon.gov.ua/storage/app/ media/zagalna\%20 serednya/ BOOKLETTE INFO-ZAKON2018 PRESS.p̄ $\bar{d} f$

Pid̄lasiy, I. P. (2019). Jak staty kompetentnym pedahohom? [How to become a competent teacher?]. (Part 1). Kharkiv : Publishing group "Osnova".

Pidlasiy, I. P. (2019). Jak staty kompetentnym pedahohom? [How to become a competent teacher?]. (Part 2). Kharkiv : Publishing group "Osnova".

Pidlasiy, I. P. (2019). Jak staty kompetentnym pedahohom? [How to become a competent teacher?]. (Part 3). Kharkiv : Publishing group "Osnova".

Rezultaty PISA po Ukraine. [Results from PISA to Ukraine]. Retrieved from https:// osvitoria.media/experience/ rezultaty-pisa-po-ukrayini-vchomu-nashi-sylni-storony/
Liashenko, O. I., Zhuk, Yu. O., Vashchenko, L. S., Naumenko, S. O., Hryvko, A. V. (2017). Testovi tekhnolohii otsiniuvannia kompetentnostey uchniv. [Test technologies of evaluation of students competence]. Kyiv.

Tokareva, N. M. (2013). Osnovy pedahohichnoi psykholohii. [Basic of pedagogical psychology: an educationalmethodical students book]. Kryvyi Rih.

Dwayne Priester Middle School Principal. (2017). Retrieved from https:// www.midpac.edu/blogs/dpriester/ 2017/11/middle-school-corecompetencies.php.

Jan, Fazlagi?, (2018). Szkola dla innovatora. Ksztaltowanie kompetencji proinnowacyjnych. [School for innovator. Formation of innovations competence]. Kalisz.

Marzec, H. (2014).

Wsp??czesny nauczyciel, jego zadania i rozw?j zawodowy. [The modern teacher, his tasks and professional development]. The image of the modern teacher, 8 (147).

OECD. (2017). PISA for Development Assessment and Analytical Framework: Reading, Mathematics and Science, Preliminary Version, OECD Publishing, Paris. Retrieved from https://www.oecd.org/pisa/pisafor - development/P I S A - D Assessment-and-AnalyticalFramework-Ebook.pdf [in English].

PISA. (2021). Mathematics Framework. Retrieved from https:/ /pisa2021-maths.oecd.org/

Стаття надійшла 07.04.2020 p. 